\title{
Geotechnical properties of residual soils from the North-east of Argentina
}

\author{
Gustavo O. Bogado, Hugo O. Reinert \& Franco M. Francisca
}

To cite this article: Gustavo O. Bogado, Hugo O. Reinert \& Franco M. Francisca (2017):

Geotechnical properties of residual soils from the North-east of Argentina, International Journal of Geotechnical Engineering, DOI: 10.1080/19386362.2017.1326682

To link to this article: http://dx.doi.org/10.1080/19386362.2017.1326682

曲 Published online: 14 May 2017.

Submit your article to this journal $\pi$

Q View related articles ¿

View Crossmark data \lceil 


\title{
Geotechnical properties of residual soils from the North-east of Argentina
}

\author{
Gustavo O. Bogado a,b,c (D), Hugo O. Reinerta (D) and Franco M. Franciscab,c \\ aFacultad de Ingeniería, Universidad Nacional de Misiones, Oberá, Argentina; bFacultad de Ciencias Exactas Físicas y Naturales, Universidad Nacional de \\ Córdoba, Córdoba, Argentina; 'Instituto de Estudios Avanzados en Ingeniería y Tecnología (IDIT, UNC-CONICET), Córdoba, Argentina
}

\begin{abstract}
North-east Argentina is almost completely covered by residual soils, as well as southeast Paraguay and central and southern Brazil. These residual soils arise as the result of the weathering of basalt. This article present certain mechanical, physical and chemical properties of residual soils from Oberá, Misiones, in north-east Argentina based upon tests on specimen from 71 boreholes. Changes in the mineralogical, physical and geomechanical characteristics with depth are related to different degrees of weathering. The correlations between different soil properties are presented and analysed and mean and coefficient of variation of the most significant soil properties is discussed and compared with results reported for similar soils from different places. The results indicate that the studied residual soils have physical, mineralogical and mechanical properties that are highly dependent on the level of alteration. Variability of soil properties increases at higher levels of degradation and chemical alteration.
\end{abstract}

ARTICLE HISTORY

Received 12 September 2016 Accepted 29 April 2017

\section{KEYWORDS}

Residual soil; mechanical properties; physical properties; weathering

\section{Introduction}

Residual soils are characterised by the different chemical, physical and biological processes that modify the structure and primary minerals of intact rock. A weathering profile arises as a consequence of the transformation of rock mass into soil particles, decreasing its apparent density and increasing the hydraulic conductivity of the porous media (Gidigasu 2012; Huat, Toll, and Prasad 2012; Rocchi and Coop 2015). The geotechnical characteristics of residual soils differ from those of transported soils in their high dependence on the degree of decomposition resulting from their genesis. Climate, topography and drainage conditions affect soil genesis (Fookes 1997; Singh, Sharma, and Tobschall 2005; Huat, Gue, and Ali 2007; Toll 2012). Physical and chemical weathering are responsible for: (a) decrease in particle size and changes in mineralogy (Fookes 1997; Rahardjo et al. 2004; Zhang et al. 2017), (b) decrease in bond strength between particles (Leroueil and Vaughan 1990), (c) increase in porosity and permeability (Samingan, Leong, and Rahardjo 2003; Wesley 2009, 2010), (d) loss in stiffness and soil density (Wesley 2010; Rahardjo et al. 2012; Blight and Leong 2012), (e) induced changes in the physical and mechanical soil properties (Charles, Leung, and Lau 2004; Pineda, Colmenares, and Hoyos 2014; Rocchi and Coop, 2015) and (f) changes in soil fabric due to wetting and drying cycles (Gullà, Mandaglio, and Moraci 2006; Pineda, Colmenares, and Hoyos 2014). Thus, weathering is a phenomenon of great importance in the geotechnical behaviour of residual soils.

Physical weathering affects parent material without inducing changes in chemical and mineralogical properties. Common physical processes are joint decompression, thermal expansion/ contraction, crystal growth and organic activity (Mitchell and Soga 2005). Chemical weathering is a complex phenomenon that affects chemical composition and mineralogy through reactions with water, dissolved ions, oxygen and carbon dioxide (Wesley 2009; Huat, Toll, and Prasad 2012). Common reactions responsible for chemical weathering include hydrolysis, chelation, ion exchange, oxidation and carbonation (Blight and Leong 2012). Cellular micro-organisms (bacteria, algae and protozoa) and fungi are frequently found in weathering profiles, acting simultaneously with the processes described above. Different phenomena take place together, making it difficult to isolate chemical, physical and biological contributions to the weathering of rocks.

Near the surface soils suffer pedogenic processes that promote the addition, loss, and transformation of the material. The main processes are eluviation-illuviation that involves the loss and addition of material, respectively, leaching that removes soluble salts and lateralisation (Vaz 1996). Gidigasu (2012) indicates that lateralisation involve the leaching, under appropriate drainage conditions, of combined silica and bases and a relative accumulation of oxides and hydroxides of sesquioxides (mainly $\mathrm{AlO}_{3}$, $\mathrm{Fe}_{2} \mathrm{O}_{3}$ and $\mathrm{TiO}_{2}$ ).

Vargas (1974) proposed a weathering profile for residual soils from Brazil derived from granite, gneisses and basalts. The author defined the upper soil layers as 'mature residual soils' what it is now known as lateritic soils and the soil layer below it as 'young soils' or saprolite. The term lateritic soil and saprolite were adopted during the International Conference on Tropical Soils in 
1985. Saprolite refers to that part of the weathering profile where the soil largely preserves the microfabric and volume of the parent rock (Aydin 2006; Lacerda 2010; Pineda, Colmenares, and Hoyos 2014).The criteria for soil to be described as saprolite is (Wesley 2010): (a) it is soils in the geotechnical sense, (b) it exhibits clear inherited structural features that make possible the identification of the parent rock and (c) it is authentically residual, meaning it is derived directly from the weathering of the rock below it.

Vaz (1996) presents a weathering profile for tropical regions, with soil and rock horizons based on the excavation and drilling methods. Two horizons for soil and three for rocks are identified based on pedogenetic changes and the degree of alteration of the parent rock. According to Vaz (1996), the mature residual soil, or eluvial soil, has homogeneous characteristics in terms of colour, grain size and mineralogical composition, the total absence of texture and structure of the rock matrix (relict structures). The young residual soil, or saprolite, is a soil layer where pedogenetic processes are incipient or very limited. On the other hand, Gidigasu (2012) and Mitchell and Soga (2005) define laterite as the soil with a silica to alumina ratio $\left(\mathrm{SiO}_{2} / \mathrm{Al}_{2} \mathrm{O}_{3}\right)$ lower than 1.33 , while in lateritic soils this ratio falls to between 1.33 and 2.00 , and when it surpasses 2.00 the soils are known as non-lateritic tropically weathered soils.

Several researchers have work on classification, microstructure and main properties of residual soils from Brazil, Malaysia and many other places around the world (Gutierrez, Nóbrega, and Vilar 2009; Futai, Almeida, and Lacerda 2004; Rahardjo et al. 2004, 2012). However, there is no database for residual soils from Argentina. The purpose of this work is to analyse and discuss the main physical, chemical, mineralogical and geotechnical properties of residual soils from Oberá, Misiones, in the north of Argentina, with the objective of determining the effect of variability due to in-depth weathering. Obtained results are compared with other works on residual soils.

\section{Degree of weathering}

Following procedure developed by Vaz (1996), the weathering profiles were divided into two significant horizons for residual soils: (a) eluvial soil which is homogeneous and shows no more traces of the original rock and (b) saprolite that shows significant heterogeneities and still maintain several properties inherited from the parent rock. The degree of alteration of the material was evaluated by determining two weathering indexes. The first determines the degree of weathering from the silica to sesquioxide ratio, as follows (Fookes 1997; Gidigasu 2012):

$$
\mathrm{Kr}=\left(\frac{\frac{\% \mathrm{SiO}_{2}}{60}}{\frac{\% \mathrm{Al}_{3} \mathrm{O}_{2}}{102}}+\frac{\% \mathrm{Fe}_{2} \mathrm{O}_{3}}{160}\right)
$$

This index identifies lateritic soils. Values of $\mathrm{Kr}<2.0$ are typical of oxide-rich ferrallitic soils, ferrisols and some ferruginous soils, whereas fersiallitic and some ferruginous soils have $\mathrm{Kr}$ values $>2.0$; ferrites, ferrallites, allites and most indurated ferrallitic soils have $\mathrm{Kr}$ values $<1.33$.

The second index was the Weathering Index of Parker (1970) (WIP) that considers $\mathrm{Na}^{+}, \mathrm{K}^{+}, \mathrm{Ca}^{+}$and $\mathrm{Mg}^{2+}$ mobilisation and leaching as follows:

$$
\mathrm{WIP}=\left(\frac{\mathrm{Na}^{+}}{0.35}+\frac{\mathrm{Mg}^{2+}}{0.9}+\frac{\mathrm{K}^{+}}{0.25}+\frac{\mathrm{Ca}^{+}}{0.7}\right) \cdot 100
$$

Different WIP values indicate the probability of ions of being mobilised due to weathering. Close to 0 values corresponds to higher rock alteration while values close to 100 are obtained in less weathered rock materials.

\section{Geology of the study area}

Oberá City in Misiones Province is in the north of Argentina (latitude $27^{\circ} 29^{\prime} 00^{\prime \prime} \mathrm{S}$ and longitude $55^{\circ} 08^{\prime} 00^{\prime \prime} \mathrm{O}$ ) (Figure 1). The climate is subtropical without a dry season, with annual mean highest and lowest temperatures of 26.5 and $16.0^{\circ} \mathrm{C}$, respectively, and mean precipitation close to $2300 \mathrm{~mm}$ /year. These conditions, the abundant subtropical rainforest and its relatively flat topography favour the weathering of rock and the formation of residual soils.

The study area is a small part of the largest continental flood basalt in the world, the Serra Geral formation, located in the south of Brazil, east of Paraguay, north-east Argentina and part of Uruguay (Gentili and Rimoldi 1979; Fodor, Corwin, and Sial 1985). This volcanic formation ranges in age from Late Jurassic to Early Cretaceous and is composed of interstratified layers of basalt and sandstones. It is represented in the study area by the Posadas Member (magmatic) and the Solari Member (clastic), as described by Herbst (1971) and Remesal et al. (2011).

Near the soil surface, there is organic soil that suffers significant wet-dry cycles due to the weather conditions. The organic matter content and the influence of the climate are progressively reduced with depth (Wesley 2010; Blight and Leong 2012). Weathering of the Posadas and Solari Members originate a saprolite layer, also known as 'young soil' (Vargas 1974), and near the soil surface eluvial soils, also known as lateritic or 'madure' soils, arises as the consequence of pedogenic process. These soils have a reddish colour, are rich in iron and aluminium oxides and contain high kaolinite content (Reinert 2007). This area was selected given that its geology can be considered as representative of extensive areas of South America and many places around the world with similar geologic formations. The results obtained may thus be relevant for many other places, not only northern Argentina but also neighbouring countries with similar soil profiles, where important infrastructure projects may be constructed in the future.

\section{Materials and methods}

Representative samples were taken from the Posadas and Solari Members from 71 site explorations performed in a $52 \mathrm{~km}^{2}$ area in the city of Oberá, in Misiones, Argentina. The spatial distribution of the samples was fairly uniform within the study area resulting in a mean of 1.36 boreholes per $\mathrm{km}^{2}$. Disturbed specimens were obtained from the Standard Penetration Test (SPT) using the Terzaghi sampler, while thin-wall Shelby tubes were used to get undisturbed specimens (Figure 2). Eluvial soils, or 'lateritic soils' were identified from $0.3 \mathrm{~m}$ below the surface to $7.0 \mathrm{~m}$ depth, with a homogeneous red colour in all soil layer (Figure 2(a)). Saprolite was commonly found below $5 \mathrm{~m}$ depth 


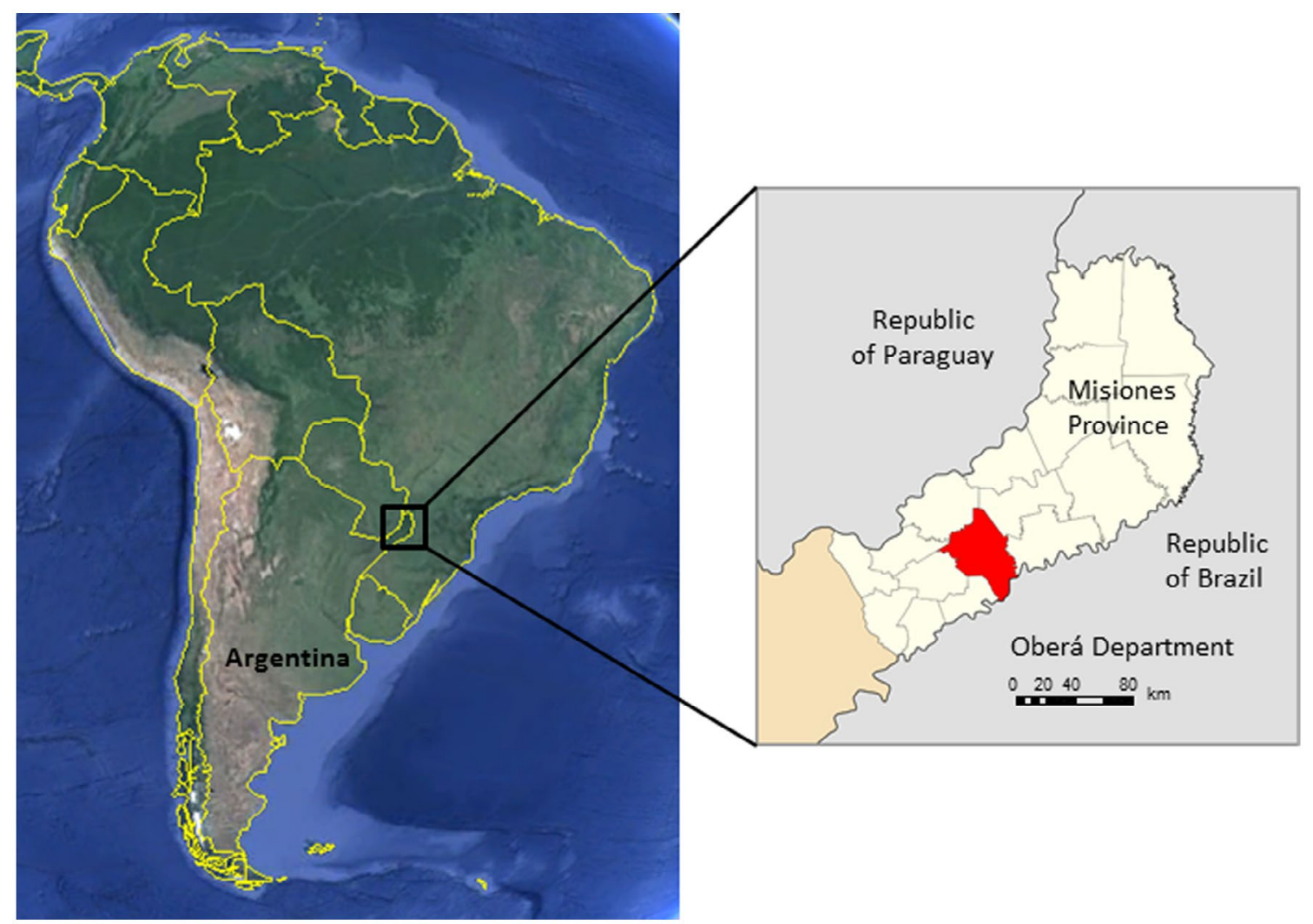

Figure 1. Location of the study area.

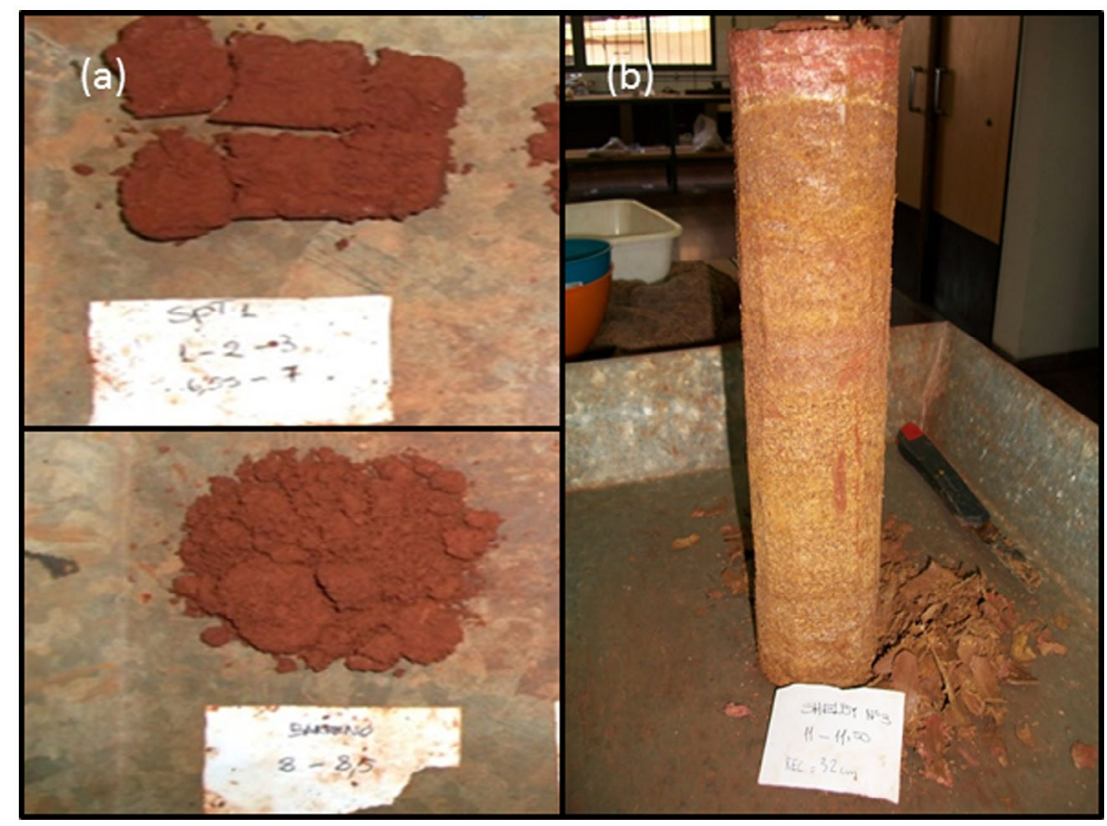

Figure 2. Representative specimens recovered with the SPT (a) and Shelby (b) tubes.

and with clear heterogeneities in colour and texture (Figure 2(b)). Most of the boreholes were drilled from the surface till the top of the weathering rock strata in order to sample specimens with different degrees of weathering.

The specimens were analysed to determine the main mineralogical, physical, chemical, and geotechnical properties of the residual soils in this region. In addition, a representative soil profile from Oberá City was selected in order to evaluate the typical vertical spatial variability of chemical properties and mineralogical composition. These properties were only determined in this representative soil profile in the borehole located at latitude S $27^{\circ} 30^{\prime} 40.24^{\prime \prime}$ and longitude W $55^{\circ} 6^{\prime} 58.70^{\prime \prime}$, due 
to time and cost issues. An excavation was performed to collect soil specimens every $0.5 \mathrm{~m}$ from the soil surface to $14 \mathrm{~m}$ in depth where a moderately weathered rock stratum was reached. This allowed specimens of eluvial soils layer to be taken from the surface to $6.3 \mathrm{~m}$ below and from the deeper saprolite to $14 \mathrm{mtrs}$ below the surface.

\section{Laboratory and field tests}

The data obtained were moisture content (ASTM D2216, ASTM 2014), unit weight and void ratio (ASTM D2167, ASTM 2014), blow count from Standard Penetration Tests (ASTM D1586, ASTM 2014), specific gravity (ASTM D854, ASTM 2014), Atterberg limits (ASTM D4318, ASTM 2014), triaxial tests (ASTM D7181, ASTM 2014) and mineralogy from the X-ray diffraction test. Special care was taken during sampling and during the storage of samples given that disaggregation, drying and moistening of soil may affect the results obtained in the case.

Even though some authors use Atterberg limits for the classification of residual soils, in the case of tropical soils the results may depend on the drying method and temperature (Vaughan, Maccarini, and Mokhtar 1988). In this work, the specimens were dried at room temperature during 60 days before testing by following recommendations given by Fookes (1997).

Grain size distribution was determined following recommendations of the ASTM D6913 (ASTM 2014) and Fookes (1997). For these experiments, the specimens were tested at natural moisture content, given that drying induces mineral degradation, and using sodium hexametaphosphate as a dispersant (Gidigasu 2012).

Consolidated drained triaxial tests were performed in the undisturbed specimens recovered with the Shelby tubes and tested at confined pressures of 50,100 and $150 \mathrm{kPa}$. The initial moisture content of the soil was between 10 and $20 \%$. All specimens were tested at natural moisture content and selected specimens were tested under saturated conditions. The results are representative for the observed behaviour under unsaturated state. Therefore, obtained results are material parameters for Mohr-Coulomb failure envelopes to be used in total stress analysis, rather than material properties.

Selected specimens from five different depths from the representative soil profile were characterised with X-ray diffraction and scanning electron microscope (SEM) tests.

Mineralogy was evaluated from X-ray diffraction test analysis, using random powders and oriented slides, with a Philips 3020 Goniometer with PW3710 Controller X-ray diffractometer with automatic slit and a Cu-Ka tube (at $\lambda=1.5406 \AA$, $40 \mathrm{kV}, 20 \mathrm{~mA}$ ). The results were analysed by the Rietveld method, and the procedure proposed by Schultz (1964) was used to semi-quantify the presence of non-clay minerals. Mineralogy of soil was determined for the total sample and clay fraction for specimens from different depths in order to evaluate the evolution of mineralogy along the weathering profile.

A high-resolution FE-SEM Eigma SEM was used to study the fabric of the eluvial soils and saprolite with complementary semi-quantitative chemical analysis by means of energy-dispersive X-ray spectroscopy (EDX) measurements.

\section{Variability and statistical analysis}

Physical and geotechnical data were analysed for the eluvial soils and saprolite in the study area. The parameters considered were blow count from SPT, void ratio, liquid limit, dry unit weight and cohesion and friction angle. Correlations between these physical and mechanical properties were determined in order to assess the coefficient of correlation and variability of soil properties. The correlation between different geotechnical properties was determined as follows:

$$
\rho_{x, y}=\frac{\operatorname{Cov}[x, y]}{\sigma[x] \sigma[y]}
$$

$$
\operatorname{Cov}[x, y]=E\left[\left(x_{i}-E[x]\right)\left(y_{i}-E[y]\right)\right]
$$

where $\rho_{x, y}=$ coefficient of correlation, $x$ and $y=$ soil properties for which correlation is determined, $\operatorname{Cov}[]=$, covariance, $E[$ ] $=$ mean value and $\sigma[]=$ standard deviation. The aim was to identify any non-apparent relationship/dependence between the properties of the different tested soils.

\section{Results}

\section{Chemical and mineralogical properties}

Figure 3 shows typical SEM images with the corresponding EDX analysis for eluvial soils (Figure 3(a) and (b)) and for saprolite (Figure 3(c) and (d)). In both cases, the soil fabric observed is dominated by clay particles and aggregation of clay particles joined by precipitated oxides and sesquioxides, which matches the arrangement proposed by Collins (1985). Specimens appear to have a porous microstructure and doughy appearance, making it difficult to individualise isolated particles, regardless of the amplification factor of the SEM. Isolated kaolinite particles were detected in only a few SEM, and the presence of iron oxides was inferred from the Fe peak identified in the EDX shown in Figure 3(b) and (d).

Figure 4 shows the diffractogram of selected eluvial soil and saprolite specimens. The mineralogical analysis of the total sample indicated that it is mainly composed by goethite $(\alpha-\mathrm{FeO}(\mathrm{OH}))$ and haematite $\left(\mathrm{Fe}_{2} \mathrm{O}_{3}\right)$ and that the fraction of goethite tended to decrease with depth (small quantities of quartz of unknown origin were identified in the eluvial soil). The analysis of the clay fraction allowed identifying kaolinite, smectite and illite as the principal clay minerals of these soils. The presence of these minerals was corroborated by testing specimens treated with ethylene glycol, after calcination in the muffle furnace. The most abundant clay mineral identified was kaolinite for all specimens with amounts that ranged from 53 to $76 \%$. Close to $10 \%$ of the smectite content was identified in the eluvial soil while a small fraction of illite (close to 5\%) was identified in the saprolite. The obtained variation of amount and type of secondary clay minerals can be associated to the different degree of weathering within the soil profile (Gidigasu 2012). 
(a)

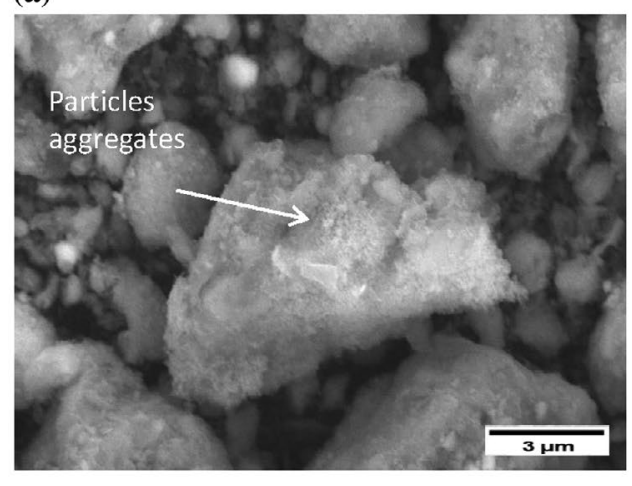

(c)

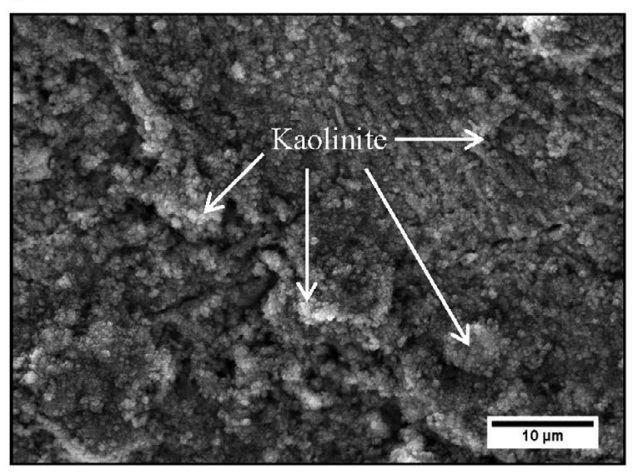

(b)

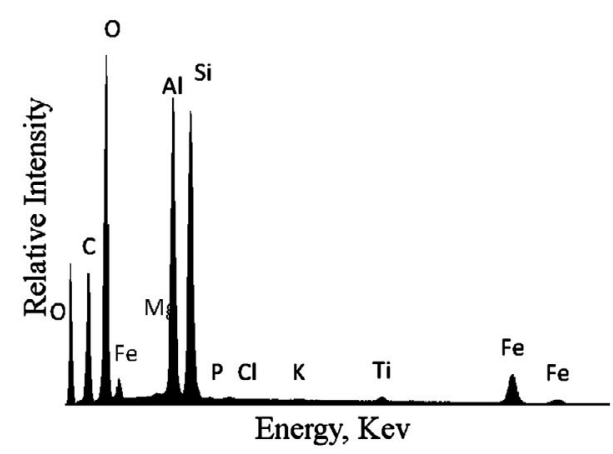

(d)

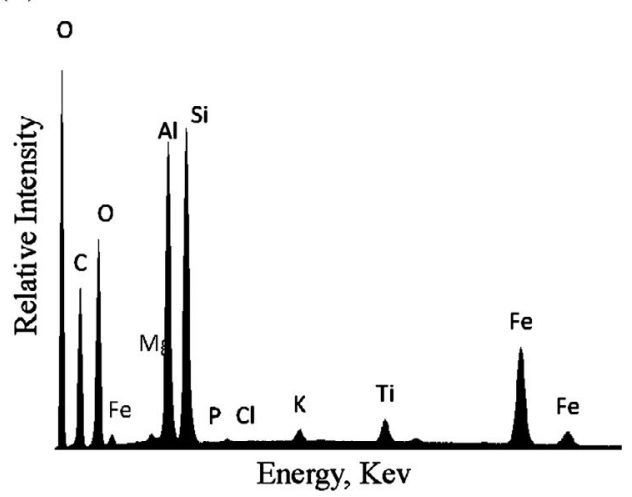

Figure 3. (a) SEM of eluvial soils at $3 \mathrm{~m}$ depth; (b) EDAX analysis of eluvial soils at $3 \mathrm{~m}$ depth; (c) SEM of saprolite at $6.5 \mathrm{~m}$ depth; (d) EDAX analysis of saprolite at $6.5 \mathrm{~m}$ depth.

(a)

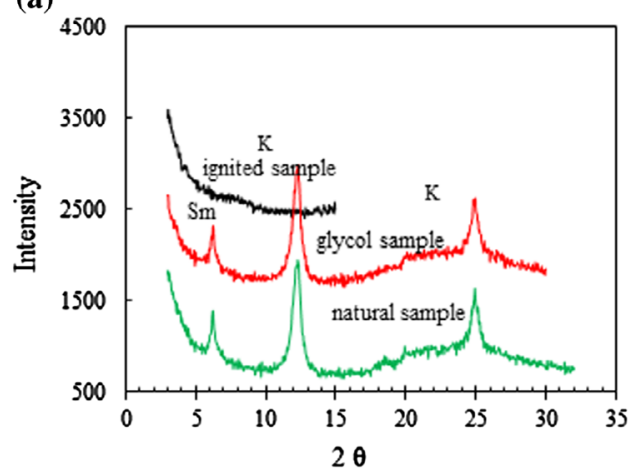

(c)

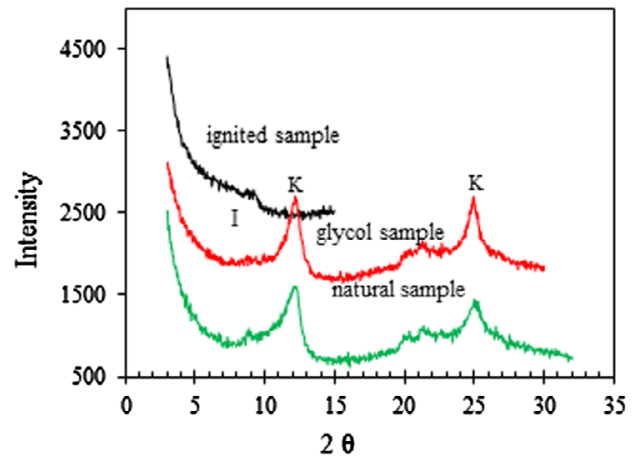

(b)

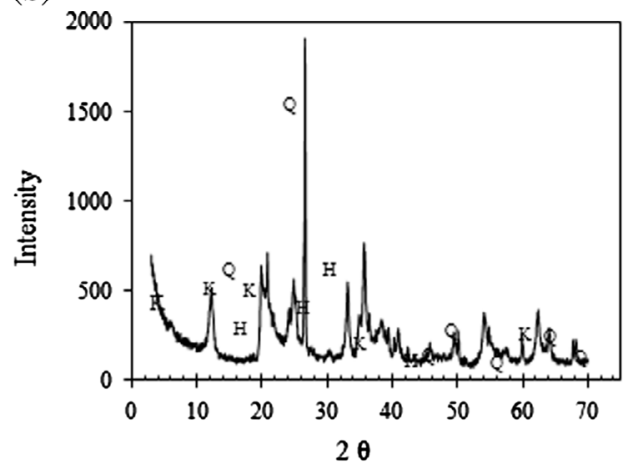

(d)

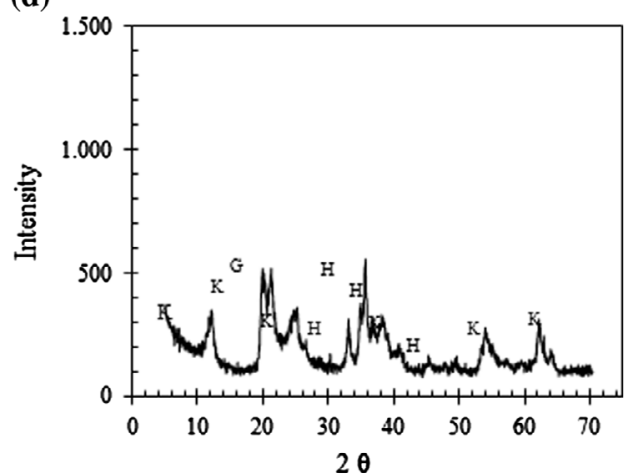

Figure 4. X-ray diffraction tests performed in eluvial soils from $4 \mathrm{~m}$ below the surface for total (a) and clay (b) fractions, and in saprolite from $12 \mathrm{~m}$ below the surface for total (c) and clay (d) fractions. 


\section{Geotechnical properties and variation with depth}

Tables 1 and 2 summarise the most significant physical and mechanical properties of the eluvial soil and saprolite, respectively, compiled from the 71 explorations performed in the study area. These tables present the mean, minimum, maximum, standard deviation and coefficient of variation (COV) of the most relevant soil properties.

As expected for this type of soils the variability in geotechnical properties tends to be higher than for transported sediments (Phoon and Kulhawy 1999). These changes in geotechnical properties can be attributed to the heterogeneous weathering and the spatial variability of soil properties, as shown by Branco et al. (2014). The COV depends on the natural variability of each soil property and also capture measurement errors (Phoon et al. 2016).

The eluvial soils have a liquid limit from 37 to $51 \%$ and a plasticity index between 5 and 32\%. The saprolites have a liquid limit from 33 to $48 \%$ and a plasticity index between 8 and $17 \%$. Figure 5 shows the liquid limit and plasticity index results in the plasticity chart. More than $95 \%$ of tested samples felt within the region of medium plasticity soil (liquid limit between 30 and $50 \%$ ). Therefore, these index properties (liquid limit and plasticity index) are within the expected values for soil with medium compressibility (Adeyemi and Wahab 2008).

The spatial variability of geotechnical properties in the vertical direction can be attributed to different degrees of alteration, even within the same zone in the soil profile (De Salvo 1990). Figure 6 shows typical variation in the vertical direction for moisture

Table 1. Variation of the main properties of eluvial soils from Oberá, Misiones.

\begin{tabular}{|c|c|c|c|c|c|c|}
\hline Properties & Unit & Max & Min & Mean & Deviation & COV (\%) \\
\hline $\begin{array}{l}\text { Moisture } \\
\text { content }\end{array}$ & $\%$ & 54.5 & 18.6 & 36.4 & 6.0 & 17 \\
\hline Liquid limit & $\%$ & 50.7 & 37.4 & 43.9 & 3.86 & 11 \\
\hline Plastic limit & $\%$ & 40.70 & 11.3 & 26.9 & 7.1 & 4 \\
\hline $\begin{array}{l}\text { Plasticity } \\
\text { index }\end{array}$ & $\%$ & 32.4 & 5.4 & 16.5 & 6.3 & 38 \\
\hline $\begin{array}{l}\text { Dry unit } \\
\text { weight }\end{array}$ & $\mathrm{kN} / \mathrm{m}^{3}$ & 16.7 & 14.3 & 12.5 & 1.0 & 8 \\
\hline Void ratio & - & 1.8 & 0.7 & 1.2 & 0.2 & 15 \\
\hline Friction angle & $\circ$ & 21.0 & 5.0 & 13.0 & 3.5 & 27 \\
\hline Cohesion & $\mathrm{kPa}$ & 13.5 & 0.5 & 4.6 & 2.7 & 58 \\
\hline $\begin{array}{l}\text { Blow count } \\
\text { (SPT) }\end{array}$ & $N$ & 15 & 5.0 & 8.3 & 2.2 & 26 \\
\hline $\begin{array}{l}\text { Passing sieve } \\
200\end{array}$ & $\%$ & 97.9 & 72.8 & 90.7 & 6.1 & 7 \\
\hline
\end{tabular}

Table 2. Variation of the main properties of saprolite from Oberá, Misiones.

\begin{tabular}{lcccccc}
\hline Properties & Unit & Max & Min & Mean & Deviation & COV (\%) \\
\hline Moisture & $\%$ & 37.9 & 15.9 & 22.7 & 9.3 & 41 \\
content & & & & & & \\
Liquid limit & $\%$ & 47.6 & 32.7 & 38.8 & 5.6 & 14 \\
Plastic limit & $\%$ & 37.6 & 18.7 & 27.4 & 6.9 & 25 \\
Plasticity index & $\%$ & 17.1 & 8.0 & 11.4 & 3.4 & 30 \\
Dry unit weight & $\mathrm{kN} / \mathrm{m}^{3}$ & 17.6 & 18.7 & 16.1 & 1.6 & 10 \\
Void ratio & - & 1.1 & 0.6 & 0.8 & 0.2 & 25 \\
Friction angle & $\circ$ & 18.8 & 10.0 & 13.9 & 3.6 & 26 \\
Cohesion & $\mathrm{kPa}$ & 8.0 & 4.0 & 6.2 & 1.3 & 22 \\
Blow count & $\mathrm{N}$ & 13 & 4 & 8.6 & 3.8 & 44 \\
(SPT) & & & & & & \\
Passing sieve & $\%$ & 75.0 & 65.0 & 69.5 & 4.8 & 7 \\
200 & & & & & & \\
\hline
\end{tabular}

content, unit weight, void ratio, specific gravity, cohesion and friction angle. The natural moisture content shows significant variations and, in general, mean values for saprolite are lower that for eluvial soils (Figure 6(a)). The specific gravity (Figure 6(b)) ranged from 2.65 to 2.85 , which is within the values in the literature for basalt-derived residual soils as studied here (Sandroni 1985). The slight decrease of specific gravity with depth observed in the eluvial soil and saprolite zones may be produced by the mineralogical changes that these soils suffer within the weathering profile (Blight and Leong 2012). The obtained changes of specific gravity with depth are in good agreement with the variations of kaolinite, oxides and sesquioxides with depth shown in Figure 4. Figure 6(c) shows the influence of depth on the soil void ratio. Very high void ratios were obtained for the entire soil profile. The decrease in void ratio with depth can be associated with a lower degree of alteration of the rock. The unit weight tends to increase with depth as expected due to the lower void ratio and degree of weathering of deeper specimens (Figure 6(d)). The Mohr-Coulomb parameters are presented in Figure 6(e) and (f). Cohesion of eluvial soils resulted between 2 and $45 \mathrm{kPa}$ while for saprolito were from 2 to $20 \mathrm{kPa}$. The high variation on friction angles can be associated with differences in soil texture and particle size distribution with depth, as reported by Blight and Leong (2012).

The degree of weathering for the selected soil profile was quantitatively determined by means of Equation (2) (Table 3). Values for WIP decreased from 90 near the soil surface to 45 for the specimen taken from $12.3 \mathrm{~m}$, which is in agreement with the variation of specific gravity and void ratio with depth shown in Figure 6 . This can be attributed to greater biological influence (e.g. roots) and infiltration of water from rainfall near the surface. In addition, the silica to sesquioxide ratio $(K r)$ defined in Equation (1) was greater than 2 in all cases, indicating that the tested specimens correspond to fersiallitic tropical soils (Fookes 1997).

The intensity of weathering not only generates secondary minerals but also alters soil texture (or grain size distribution) (Rahardjo et al. 2004). Figure 7 shows the influence of depth on grain size distribution. Clearly soil texture, the sand, silt and

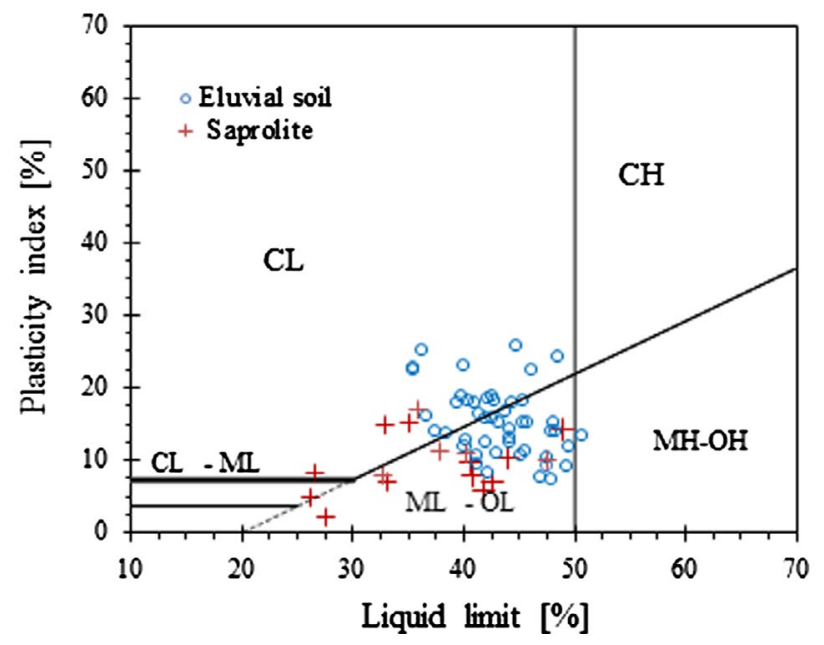

Figure 5. Plasticity chart. 
(a)

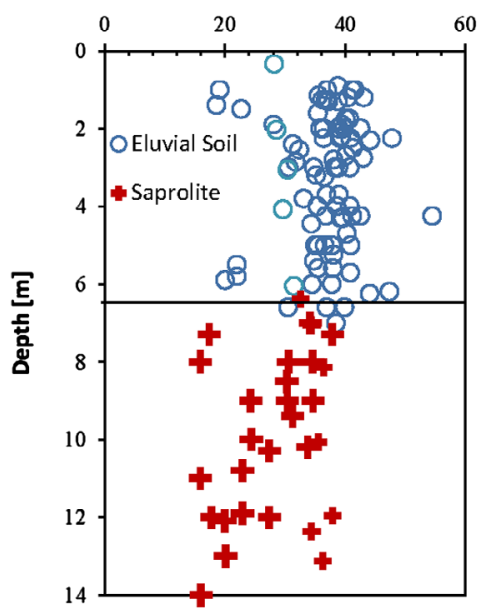

(d)

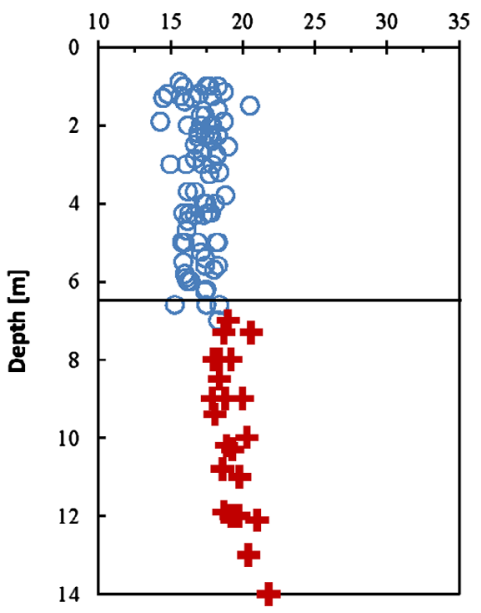

(b)

Specific Gravity

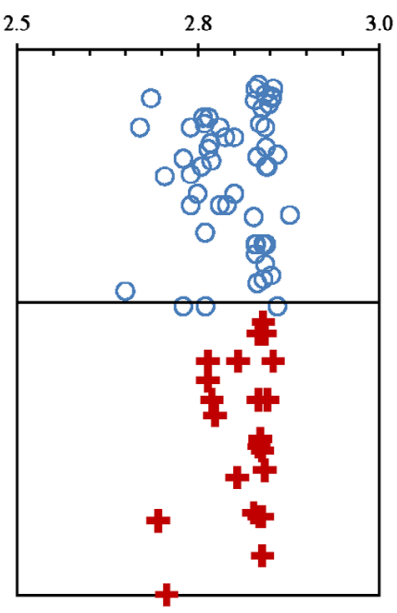

(e)

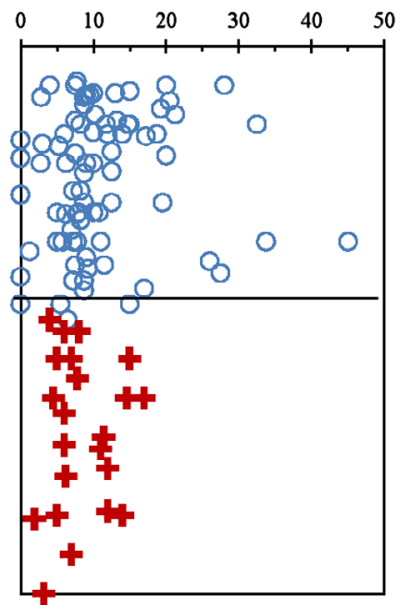

(c) Void radio

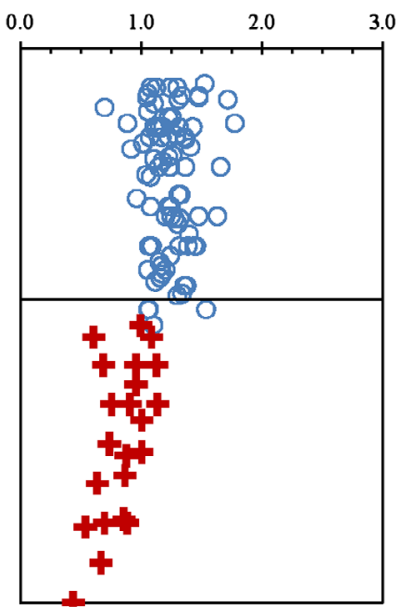

(f)

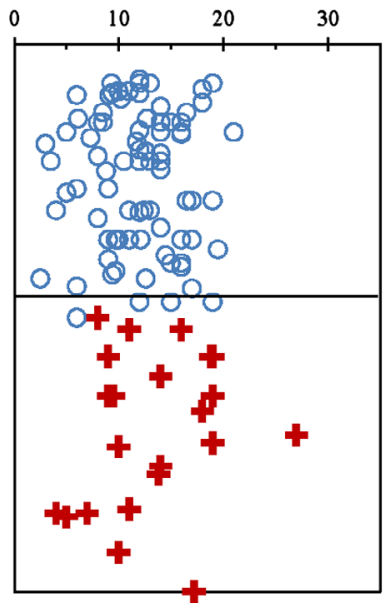

Figure 6. Variation with depth of moisture content (a), specific gravity (b), void ratio (c), unit weight (d), cohesion (e) and (f) friction angle.

Table 3. Weathering indexes.

\begin{tabular}{lcrrrrrr}
\hline Depth $(\mathrm{m})$ & $\mathrm{SiO}_{2}$ & $\mathrm{Al}_{2} \mathrm{O}_{3}$ & $\mathrm{Fe}_{2} \mathrm{O}_{3}$ & $\mathrm{Na}_{2} \mathrm{O}$ & $\mathrm{K}_{2} \mathrm{O}$ & $\mathrm{CaO}$ & WIP \\
\hline 0.30 & 42.42 & 9.95 & 6.67 & 0.04 & 0.08 & 0.01 & 45.3 \\
3.00 & 32.57 & 12.60 & 12.13 & 0.01 & 0.12 & 0.01 & 59.1 \\
6.30 & 15.96 & 10.84 & 30.85 & 0.05 & 0.79 & 0.01 & 81.6 \\
8.10 & 36.68 & 9.97 & 9.74 & 0.70 & 0.25 & 0.12 & 87.9 \\
12.30 & 28.15 & 11.14 & 9.97 & 0.60 & 0.15 & 0.30 & 90.0
\end{tabular}

clay fractions, changes through the soil profile. The clay fraction decreased from $60 \%$ near the surface to close to $35 \%$ at $12.3 \mathrm{~m}$ while the opposite trends were obtained for the silt and sand fraction that increased with the soil depth. These trends can be attributed to the lower degree of weathering expected at higher depth (Northmore et al. 1992).

Figure 8 shows the probabilistic distribution of the void ratio measured for eluvial soil and saprolitic soils. Void ratios were clearly higher than 1 in more than $90 \%$ of eluvial soil specimens tested (Figure 8(a)) and lower than 1 in more than $95 \%$ of the saprolite samples (Figure 8(b)). These results match previous results reported in the literature (Fookes 1997).

The variability of geotechnical properties in eluvial soils is mainly associated with weathering as well as with the natural

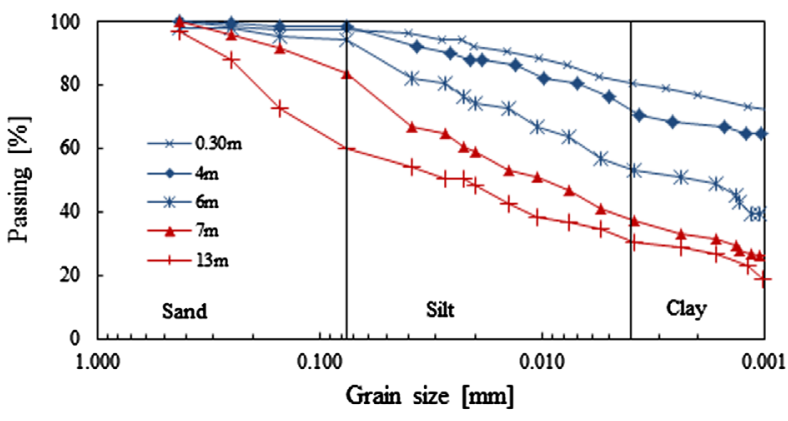

Figure 7. Typical evolution of the grain size distribution with depth.

variation of soil properties vertically and horizontally. In addition, saprolites frequently contain randomly oriented discontinuities and a cemented structure, affecting the mechanical properties of these soils (Aydin 2006).

The results of SPT blow counts, void ratio, liquid limit, dry unit weight, cohesion and friction angle were statistically analysed in order to identify correlations between each other. These correlations can be seen in the figure matrix in Figure 9, while the COV for each parameter is given in Tables 1 and 2. With this 

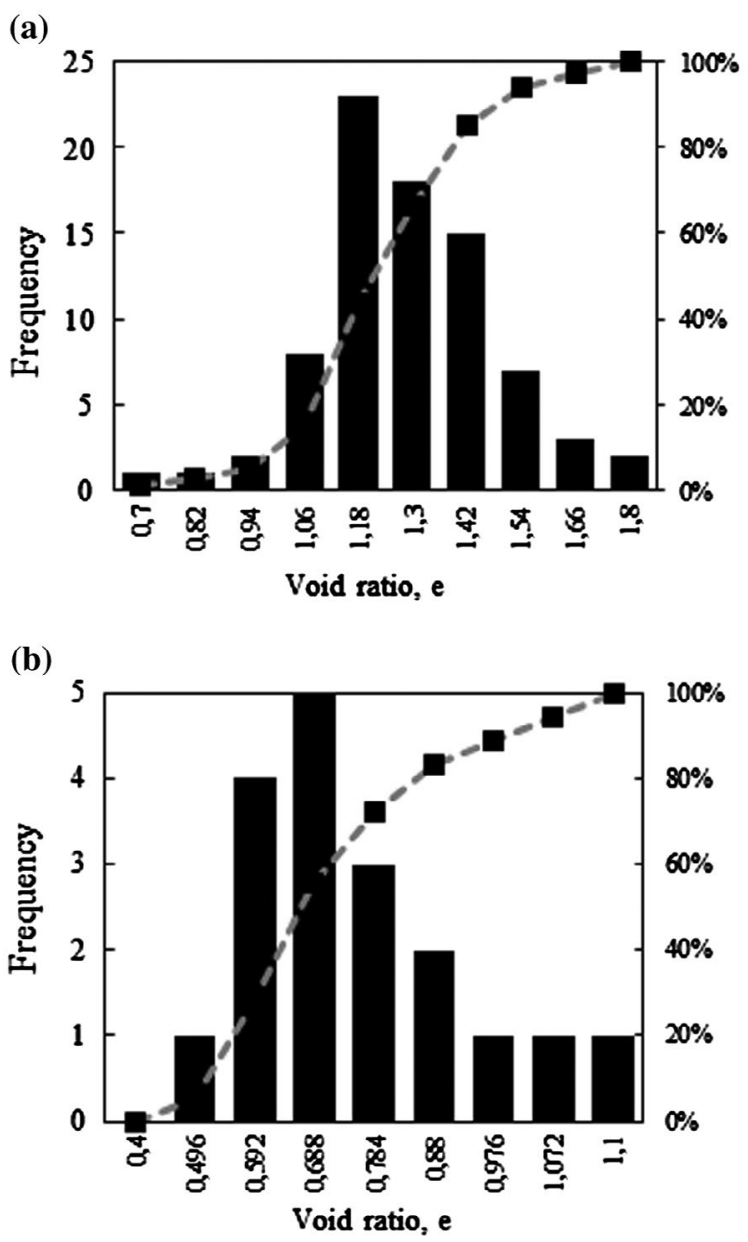

Figure 8. Histogram of void ratios of eluvial soils (a) and saprolite (b).

analysis, we were able to evaluate the possibility of estimating mechanical properties from physical indexes determined by routine testing (Que et al. 2008). In terms of correlation coefficient, no relationship with $\rho_{x, y}>0.5$ was obtained for the eluvial soils, while strong positive correlations for the saprolite were obtained between liquid limit and void ratio $\left(\rho_{\mathrm{LL}, e}=0.91\right)$, between liquid limit and cohesion $\left(\rho_{\mathrm{LL}, \mathrm{cu}}=0.70\right)$, and between blow count and friction angle $\left(\rho_{N, \phi}=0.51\right)$.

Soil properties measured either in laboratory or in the field are fundamental inputs for numerical and conceptual models used in engineering design (Abad et al. 2016; Phoon et al., 2016). With this purpose, the determination of the variability of geotechnical properties, expressed in Figure 9, are useful to perform sensibility analysis and reliability based design (RBD). The results presented in Figure 9, and Tables 1 and 2 enable the most significant geotechnical properties to be quantified and their variability to be assessed. The variability quantified here can provide insight about the behaviour of residual soil with similar geomechanical properties (Rahardjo et al. 2012).

\section{Discussion}

The results presented herein are useful to compare variability and trends with data available in recent literature for similar residual soils.

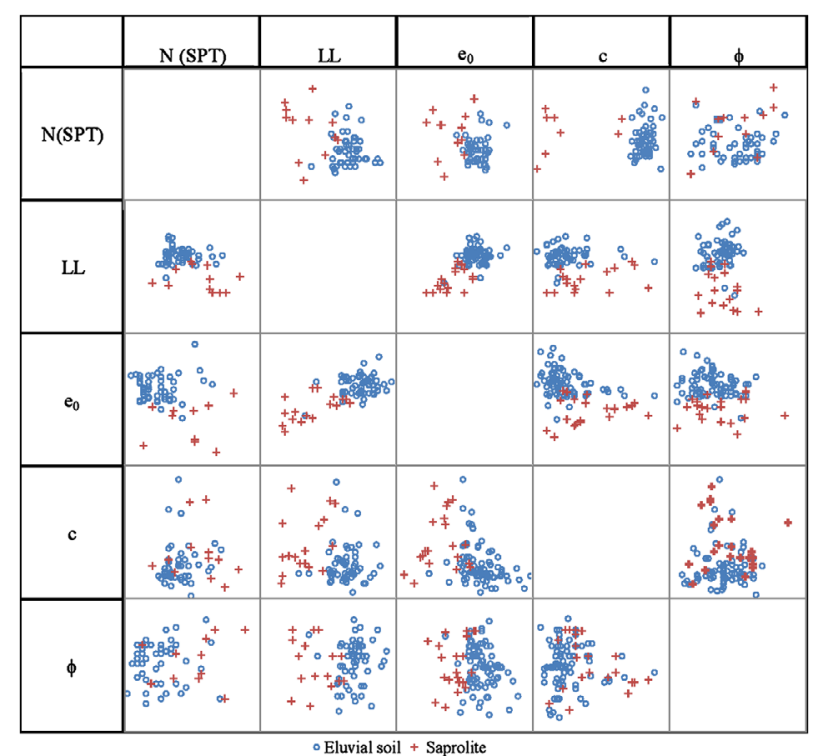

Figure 9. Figure matrix showing relationships between the different geotechnical properties for eluvial soils and saprolite.

The mean and COV of LL for the eluvial soil were 43.9 and $11 \%$. In the case of saprolite the mean and COV of LL were 38.8 and $14 \%$. These results are in good agreement with data reported by West and Dumbleton (1970) and Lohnes et al. (1983). Also, the COV of LL for eluvial soil and saprolite were between 10 and 20\% which is the range suggested by Harr (1977). West and Dumbleton (1970) reported mean LL $=49 \%$ and COV $=3.1 \%$ for residual soil derived from basalt in Malaysia, while Lohnes et al. (1983) indicated that residual soils also derived from basalt in Hawaii has mean $\mathrm{LL}=47 \%$ and $\mathrm{COV}=2.0$. Mean and $\mathrm{COV}$ of PL for the eluvial soil were 26.9 and $4 \%$ while for saprolite were 11.1 and 30\%. Ugbe (2011) tested residual soils derived from basalt in Nigeria and obtained mean LL $=36.4 \%$ with a $\mathrm{COV}=18 \%$, and a mean $\mathrm{PL}=14.5 \%$ with a COV $=19 \%$. In the case of plasticity index, results reported in this work are also in good agreement with those reported by Ugbe (2011).

In the case of void ratio, the obtained mean values (Tables 1 and 2) were slightly higher than those measured by Miguel and Villar (2009) in residual soils from Brazil. Significantly lower values were reported by Rahardjo et al. (2012) in residual soils derived from granite. The wide range of mean void ratio for residual soils reported in literature can be attributed to its dependence on parental rock type and degree of weathering as indicated by Wesley (2009).

Finally, the unsaturated friction angle and cohesion reported in this work were controlled by the soil type and test conditions. Rahardjo et al. (2012) indicated that a decrease of fine content emerges as decreases in cohesion. Measured friction angles show significant variability that can be associated with differences in soil texture and particle size distribution, as reported by Blight and Leong (2012). Also the variability in the degree of weathering and the difficulty in obtaining high quality samples can be responsible for this trend (Rahardjo et al. 2012). As consequence, the COV for the Mohr-Coulomb envelope parameters obtained in this work resulted slightly higher or close to the upper limit suggested by Harr (1977). 


\section{Conclusions}

This study analyses the main physical, chemical, mineralogical and geotechnical properties of residual soils from the north-east Argentina. The main conclusions can be summarised as follows:

- The mineralogical and physical properties of the residual soils are the result of the weathering of basalt. Rock alteration induces changes in soil structure within the soil profile, which are manifest in significant variations in void ratio, granulometry and mineralogy with depth. The most abundant mineral in all the soil profile is kaolinite, according to the X-ray diffraction test results. Other minerals found in less proportion include illite, goethite, smectite, quartz and haematite.

- The silica to sesquioxide ratio is higher than 2 for the eluvial and saprolitic soils, characterising the tropical soil tested as fersiallitic. Oxides and sesquioxides joint clay particles and aggregation of clay particles and therefore are responsible for the soil fabric as observed in the SEM images.

- The spatial variability of granulometry, clay content, void ratio, liquid limit and plasticity index in the vertical direction are useful properties for evaluating the degree of weathering of soils. The average plasticity index and liquid limit values are higher for eluvial soil than for saprolite.

- Geomechanical properties show a complex heterogeneity that makes it difficult to relate mechanical and index properties in the eluvial soil and the saprolite. This can be attributed to the high variability in soil properties associated with local weathering conditions. Additional soil data is needed in order to characterise the effect of field scale heterogeneities on the geotechnical properties. These properties are fundamental for the design of geotechnical structures in north-east Argentina, but our results may also be relevant for other sites with residual soils with similar properties.

\section{Disclosure statement}

No potential conflict of interest was reported by the authors.

\section{Funding}

This work was supported by Consejo Nacional de Investigaciones Cientificas y Técnicas [grant number $11220150100298 \mathrm{CO}$ ] and Fondo para la Investigación Cientifica y Tecnológica [grant number PICT-2014-3101].

\section{ORCID}

Gustavo O. Bogado (iD http://orcid.org/0000-0003-1807-9733

Hugo O. Reinert (iD http://orcid.org/0000-0001-8926-6742

\section{References}

Abad, S. A., A. Tugrul, C. Gokceoglu, and D. J. Armaghani. 2016. "Characteristics of Weathering Zones of Granitic Rocks in Malaysia for Geotechnical Engineering Design.” Engineering Geology 200: 94-103.

Adeyemi, G. O., and K. A. Wahab. 2008. "Variability in the Geotechnical Properties of a Lateritic Soil from South Western Nigeria." Bulletin of Engineering Geology and the Environment 67 (4): 579-584. .
ASTM. 2014. Annual Book of ASTM Standards. Vol. 04.08. West Conshohocken, PA.

Aydin, A. 2006. "Stability of Saprolitic Slopes: Nature and Role of Field Scale Heterogeneities." Natural Hazards and Earth System Science 6 (1): 89-96.

Blight, G. E., and E. C. Leong. 2012. Mechanics of Residual Soils. 2nd ed. London: Taylor \& Francis.

Branco, L. P., A. T. Gomes, A. S. Cardoso, and C. S. Pereira. 2014. "Natural Variability of Shear Strength in a Granite Residual Soil from Porto." Geotechnical and Geological Engineering 32 (4): 911-922.

Charles, W. W., E. H. Leung, and C. K. Lau. 2004. "Inherent Anisotropic Stiffness of Weathered Geomaterial and Its Influence on Ground Deformations around Deep Excavations." Canadian Geotechnical Journal 41 (1): 12-24.

Collins, K. 1985. "Towards Characterization of Tropical Soil Microstructure." 1st Conference in Geomechanics in Tropical Lateritic and Saprolitic Soils, Brazil, vol. 1, 85-96.

De Salvo, O. E. 1990. "El Perfil De Meteorización De Las Rocas Basálticas Y Su Importancia En La Ingeniería De Fundaciones." Revista Técnica De Las Asociaciones Paraguayas De Estructuras Y Geotecnia 1: 33-46.

Fodor, R. V., C. Corwin, and A. N. Sial. 1985. "Crustal Signatures in the Serra Geral Flood-Basalt Province, Southern Brazil: O- and Sr-Isotope Evidence." Geology 13: 763-765.

Fookes, P. G. 1997. Tropical Residual Soils: A Geological Society Engineering Group. Working Party Revised Report. London: Geological Society of London.

Futai, M. M., M. S. S. Almeida, and W. A. Lacerda. 2004. "Yield, Strength, and Critical State Behavior of a Tropical Saturated Soil." Journal of Geotechnical and Geoenvironmental Engineering 130 (11): 1169-1179.

Gentili, C. A., and H. R. Rimoldi. 1979. "Mesopotamia." En Geología Regional Argentina, 185-223. Córdoba: Academia Nacional de Ciencias.

Gidigasu, M. D. 2012. Laterite Soil Engineering: Pedogenesis and Engineering Principles. Amsterdam: Elsevier.

Gullà, G., M. C. Mandaglio, and N. Moraci. 2006. "Effect of Weathering on the Compressibility and Shear Strength of a Natural Clay." Canadian Geotechnical Journal 43 (6): 618-625.

Gutierrez, N. H. R., N. T. Nóbrega, and O. Vilar. 2009. "Influence of the Microstructure in the Collapse of a Residual Clayey Tropical Soil." Bulletin of Engineering Geology and the Environment 68: 107-116.

Harr, M. E. 1977. Mechanics of Particulate Media. New York: McGraw Hill.

Herbst, R. 1971. "Esquema Estratigráfico De La Provincia De Corrientes, República Argentina." Revista De La Asociación Geológica Argentina, Buenos Aires 26: 221-243.

Huat, B. B., S. S. Gue, F. H. Ali. eds. 2007. Tropical Residual Soils Engineering. New York: CRC Press.

Huat, B. B., D. G. Toll, and A. Prasad. 2012. Handbook of Tropical Residual Soils Engineering. New York: CRC Press.

Lacerda, W. A. 2010. "Shear Strength of Soils Derived from the Weathering of Granite and Gneiss in Brazil." Geological Society, London, Engineering Geology Special Publications 23 (1): 167-182.

Leroueil, S., and P. R. Vaughan. 1990. "The General and Congruent Effects of Structure in Natural Soils and Weak Rocks." Géotechnique 40 (3): 467-488.

Lohnes, R.A., and T. Demirel. 1983. "Geotechnical Properties of Residual Tropical Soils." In Geological Environmental and Soil Properties, ASCE, pp. 150-166.

Miguel, M. G., and O.M. Vilar. 2009. "Study of the Water Retention Properties of a Tropical Soil." Canadian Geotechnical Journal 46 (9): 1084-1092. doi: https://doi.org/10.1139/T09-039.

Mitchell, J. K., and K. Soga. 2005. Fundamentals of Soil Behavior. 3rd ed. Hoboken, NJ: Wiley.

Northmore, K. J., M. G. Culshaw, P. R. N. Hobbs, J. R. Hallam, D. C. and Entwisle. 1992. "Engineering Geology of Tropical Red Clay Soils: Summary Findings and their Application for Engineering Purposes". British Geological Survey Technical Report WN/93/15.

Parker, A. 1970. "An Index of Weathering for Silicate Rocks." Geological Magazine 107: 501-504.

Phoon, K. K., and F. H. Kulhawy. 1999. "Characterization of Geotechnical Variability." Canadian Geotechnical Journal 36 (4): 612-624.

Phoon, K. K., W. A. Prakoso, Y. Wang and J. Ching. 2016. "Uncertainty Representation of Geotechnical Design Parameters". Chap. 3 in 
Reliability of Geotechnical Structures in ISO2394. 49-88. New York: CRC Press/Balkema.

Pineda, J. A., J. E. Colmenares and L. R. Hoyos. 2014. "Effect of Fabric and Weathering Intensity on Dynamic Properties of Residual and Saprolitic Soils via Resonant Column Testing". ASTM 37 (5): 800-816.

Que, J., Q. Wang, J. Chen, B. Shi, and Q. Meng. 2008. "Geotechnical Properties of the Soft Soil in Guangzhou College City." Bulletin of Engineering Geology and the Environment 67: 479-483.

Rahardjo, H., K. Aung, E. C. Leong, and R. Rezaur. 2004. "Characteristics of Residual Soils in Singapore as Formed by Weathering." Journal of Engineering Geology 73 (1-2): 157-169.

Rahardjo, H., A. Satyanaga, E. C. Leong, Y. S. Ng, and H. T. C. Pang. 2012 "Variability of Residual Soil Properties." Engineering Geology 141-142: $124-140$.

Reinert, H. O. 2007. "Caracterización Geotécnica De Suelos Grises Del Departamento De Oberá-Misiones". Dissertation, Universidad Nacional De Córdoba.

Remesal, M. B., W. Wildner, S. Chavez, and A. A. Ardolino. 2011. "Provincia Magmatica Paraná-Etendeká: Nueva Propuesta Estratigráfica, Misiones Argentina”. XVIII Congreso Geológico Argentino, Neuquén, Argentina.

Rocchi, I., and M. R. Coop. 2015. "The Effects of Weathering on the Physical and Mechanical Properties of a Granitic Saprolite." Géotechnique 65 (6): 482-493.

Samingan, A. S., E. C. Leong, and H. Rahardjo. 2003. "A Flexible Wall Permeameter for Measurements of Water and Air Coefficients of Permeability of Residual Soils." Canadian Geotechnical Journal 40 (3): 559-574.

Sandroni, S. S. 1985. "Discussion Stress Relief Effects in Gneissic Saprolitic Soils". In Proceedings of the 1st International Conference on Geomechanics in Tropical Lateritic and Saprolitic Soils, Brasilia, vol. 3, 290-296.

Schultz, L. G. 1964. "Quantitative Interpretation of Mineralogical Composition from X-Ray and Chemical Data for the Pierre Shale." U.S. Geological Survey Professional Paper 391: 1-31.
Singh, M., M. Sharma, and H. J. Tobschall. 2005. "Weathering of the Ganga Alluvial Plain, Northern India: Implications from Fluvial Geochemistry of the Gomati River." Applied Geochemistry 20 (1): 1-21.

Toll, D. G. 2012. “Tropical Soils”. In ICE Manual of Geotechnical Engineering Vol. 1: Geotechnical Engineering Principles, Problematic Soils and Site Investigation, edited by Burland J., T. Chapman, H. Skinner and M. Brown, 341-361. ICE Publishing.

Ugbe, F. C. 2011. "Basic Engineering Geological Properties of Lateritic Soils from Western Niger Delta." Research Journal of Environmental and Earth Sciences 3 (5): 571-577.

Vargas, M. 1974. "Engineering Properties of Residual Soils Derived from Igneous and Metamorphic Rocks". In Proceedings of 2nd International Congress of the IAEG, Vol. 1, Sao Paulo, Brazil, IV-pc1-IV-pc26.

Vaughan, P. R., M. Maccarini, and S. M. Mokhtar. 1988. "Indexing the Engineering Properties of Residual Soil." Quarterly Journal of Engineering Geology and Hydrogeology 21 (1): 69-84.

Vaz, L. F. 1996. "Classificação Genética Dos Solos E Dos Horizontes De Alteração De Rochas Em Regiões Tropicais Solos E Rochas." São Paulo 19 (2): 117-136.

Wesley, L. 2009. Fundament of Soil Mechanics for Sedimentary and Residual Soils. Hoboken, NJ: Wiley.

Wesley, L. 2010. Geotechnical Engineering in Residual Soils. Hoboken, NJ: Wiley.

West, G., and M. J. Dumbleton. 1970. "The Mineralogy of Tropical Weathering Illustrated by Some West Malaysian Soils." Quarterly Journal of Engineering Geology and Hydrogeology 3 (1): 25-40.

Zhang, X. W., L. W. Kong, S. Yin, and C. Chen. 2017. "Engineering Geology of Basaltic Residual Soil in Leiqiong, Southern China." Engineering Geology 220: 196-207. 